Research Article

\title{
Grain and Flour Wheat Quality Modified by Genotype, Availability of Nitrogen, and Growing Season
}

\author{
Cristobal Valdés Valdés, ${ }^{1}$ Gaspar Estrada-Campuzano (iD, ${ }^{1}$ \\ Carlos Gustavo Martinez Rueda, ${ }^{1}$ Aurelio Domínguez López, ${ }^{1}$ Ernesto Solis-Moya, \\ and Adriana Villanueva Carvajal ${ }^{1}$ \\ ${ }^{1}$ Agricultural Sciences Faculty, Autonomous Mexico State University, Campus "El Cerrillo", km.15 Rd. Toluca-Ixtlahuaca, \\ Toluca 50200, Mexico \\ ${ }^{2}$ National Institute of Forest, Agriculture and Livestock Research (INIFAP), km. 6.5 Road Celaya-St Miguel of Allende W/n, \\ Roque, Celaya, Guanajuato, Mexico
}

Correspondence should be addressed to Gaspar Estrada-Campuzano; gestradac@uaemex.mx

Received 20 August 2019; Revised 5 March 2020; Accepted 11 March 2020; Published 9 April 2020

Academic Editor: Silvia Imhoff

Copyright (C) 2020 Cristobal Valdés Valdés et al. This is an open access article distributed under the Creative Commons Attribution License, which permits unrestricted use, distribution, and reproduction in any medium, provided the original work is properly cited.

The objective of the present study was to determine physical and chemical parameters that determine grain and flour quality of wheat grown in Mexico's highlands (Toluca, Estado de Mexico) as a response of nitrogen fertilization and growing season. Experiments were carried out in winter-spring 2010 (irrigation) and summer-autumn 2011 (rainfed) season cycles. Nine wheat cultivars were tested under four levels of nitrogen fertilization $\left(\mathrm{N}_{00}, \mathrm{~N}_{100}, \mathrm{~N}_{200}\right.$, and $\mathrm{N}_{300} \mathrm{~kg} \mathrm{~N} \cdot \mathrm{ha}^{-1}$ ) with a population density of 336 seeds $\mathrm{m}^{-2}$. For each growing season and $\mathrm{N}$ rate, three replications were performed for each experiment under a randomized complete block design. Best quality indexes were obtained in the winter-spring cycle as a result of genetic variability. Nitrogen availability modified significantly some quality parameters (grain and flour protein, test weight, and hardness) obtaining the highest values at a rate of $100 \mathrm{~kg} \mathrm{~N} \cdot h \mathrm{~h}^{-1}$. On the other hand, volume of sedimentation showed positive effects only at a rate of $300 \mathrm{~kg} \mathrm{~N} \cdot \mathrm{ha}^{-1}$. This rate showed positive effects on grain and flour protein, sedimentation volume, and hardness during the summer-autumn cycle. Eneida F94, Tollocan F2005, and Urbina S2007 cultivars presented the highest grain and flour protein content of tested varieties. Finally, Eneida F94 and Tollocan F2005 presented the highest test weight and flour percentage.

\section{Introduction}

Bread wheat is one of the most important cereal crops in the world and is grown in a wide range of environmental conditions. Wheat grain quality characteristics depend greatly on genotype, environment and genotype $\times$ environment interactions. In fact, many quality attributes such as grain protein content are modified by climatic parameters, genotype, nitrogen fertilizer rate, time of nitrogen application, and available water during grain filling [1-3]. Mexican highlands' wheat (>2000 masl) often produces grain with insufficient quality for industrial purposes (flour and bakery products) [4]. In this sense, knowing the effect of the environment and management practices (mainly the use of $\mathrm{N}$ ) on wheat quality characteristics, it would be useful to increase its industrial potential. Sowing of this crop is usually performed under rainfed conditions (summer-autumn season), but grains present marketing problems due to their low milling quality [4]. Conversely, sowing under irrigation (winter-spring season) increases industrial grain quality. There is evidence of neither environmental variables responsible for such quality differences nor the cultivars better adapted to them. Thus, to evaluate different cultivars exposed to both environments could be useful to select genotypes for specific purposes (bakery and/ or biscuit industry).

Physical characteristics such as color, test weight, and hardness determine the quality of wheat grain, so soft, hard, or very hard grains are related to kernel hardness which defines the milling and baking process [5-7]. Grain hardness 
can be affected by environmental factors such as soil type, irrigation, fertilizer, management practices, precipitation, and temperature during maturation and postripening [8]. This attribute is influenced by many factors such as kernel shape and density, agronomic practice (included nitrogen management), and climatic and weather conditions [9]. Nitrogen fertilization has a significant effect on test weight [10] as increase in nitrogen availability decreases significantly test weight in wheat but increases the amount and composition of gluten proteins (gliadins:glutenins) [11-13].

Espitia et al. [4] found that protein performance between the two seasons was different with the same $\mathrm{N}$ application, and $\mathrm{N}$ availability in soil affects quantity and quality of grain protein content [14]. Maximum temperatures during grain filling $[11,15]$ and water input during this phase [16] are also associated to grain protein content. The sedimentation test using sodium dodecyl sulphate (SDS) is a simple test to measure wheat bread-making quality on small samples and in a short period of time [17] and is modified by nitrogen availability. Saint Pierre at al. [18] found that the increase in $\mathrm{N}$ availability increased SDS value.

The aim of the present document is to determine how $\mathrm{GxE}$ interaction affects grain quality in wheat genotypes with different yield potentials. Therefore, it is important to find out whether nitrogen fertilization and growing season have a direct effect on wheat grain quality.

\section{Materials and Methods}

2.1. General Conditions. Two experiments were carried out during winter-spring (W-S) 2010 (irrigation) and summerautumn (S-A) 2011 (rainfed) seasons in the experimental field of the Agricultural Sciences Faculty of the Mexico State University (UAEMex) located $18 \mathrm{~km}$ north of the Toluca city $\left(19^{\circ} 15^{\prime} 33^{\prime \prime \prime} \mathrm{N}, 99^{\circ} 39^{\prime} 38^{\prime \prime \prime} \mathrm{W}\right.$, altitude 2640$)$. The climate of this region corresponds to type C (w2) (w) b (i), according to the Köppen climatic classification, modified by García [19], and is defined as subhumid temperate, with rains concentrated during summer and low rainfall in winter (5\%), slight thermal oscillation, annual average temperature $12.8^{\circ} \mathrm{C}$, and annual precipitation above $900 \mathrm{~mm}$. The soil is pelvic vertizol with $36 \%$ clay, apparent density $1.26 \mathrm{~g} \cdot \mathrm{cm}^{-3}, \mathrm{pH} 5.5$, the nitrogen content before sowing $0.11 \%$, phosphorus $20 \mathrm{ppm}$, and potassium $60 \mathrm{ppm}$.

2.2. Treatments and Experimental Design. Experiments consisted on a factorial combination of nine cultivars of wheat released from 1975 to 2007 and four levels of nitrogen availability. Cultivars (Salamanca S75, Saturno S86, Eneida F94, Cortazar S94, Rebeca F00, Barcenas S02, Tollocan F05, Maya S07, and Urbina S07) were selected according to their greater representation in every era, based on the acreage of each cultivar. Nitrogen availability treatments consisted of an unfertilized control $\left(\mathrm{N}_{00} \mathrm{~kg} \mathrm{~N} \cdot \mathrm{ha}^{-1}\right)$ and fertilizer treatments $\mathrm{N}_{100}, \mathrm{~N}_{200}$, and $\mathrm{N}_{300} \mathrm{~kg} \mathrm{~N} \cdot \mathrm{ha}^{-1}$ with $\mathrm{N}$ applied as urea. Urea application was split into 2 or 3 identical quantities according to the treatment, for example, $50 \mathrm{~kg} \mathrm{~N} \cdot \mathrm{ha}^{-1}$ for all rates at sowing, $50 \mathrm{~kg} \mathrm{~N} \cdot \mathrm{ha}^{-1}\left(\mathrm{~N}_{100}\right), 75 \mathrm{~kg} \mathrm{~N} \cdot \mathrm{ha}^{-1}\left(\mathrm{~N}_{200}\right)$, and
$125 \mathrm{~kg} \mathrm{~N} \cdot \mathrm{ha}^{-1}\left(\mathrm{~N}_{300}\right)$ broadcasted at terminal spikelet, and subsequently $75 \mathrm{~kg} \mathrm{~N} \cdot \mathrm{ha}^{-1}$ (N200) and $125 \mathrm{~kg} \mathrm{~N} \cdot \mathrm{ha}^{-1}\left(\mathrm{~N}_{300}\right)$ at flag leaf appearance. Application of $\mathrm{P}$ and $\mathrm{K}$ was 60 and $30 \mathrm{~kg} \cdot \mathrm{ha}^{-1}$, respectively, for all levels including the control which was applied at sowing. Within each $\mathrm{N}$ rate, the nine cultivars were distributed under a randomized complete block design with 3 replications, where each $\mathrm{N}$ rate corresponds to a particular environment.

Experiments were hand-sown at 336 seeds $\mathrm{m}^{-2}$ in plots of 6 rows, $0.20 \mathrm{~m}$ apart and $3.0 \mathrm{~m}$ long, with a separation between plots of $0.40 \mathrm{~m}$. Plots were managed to minimize interferences from biotic stress. Weeds were removed by hand to avoid any negative effect of hormonal herbicides that may have differentially affected the cultivars. Fungicides and insecticides were sprayed throughout the crop cycle to prevent or control fungal diseases and insect damages. Onwards nets were installed from the onset of stem elongation to prevent lodging.

2.3. Measurements. All experiments were conducted in the Quality Lab of National Institute of Forest, Agriculture and Livestock Research (INIFAP).

2.4. Physical Analysis. Physical analysis consisted in evaluating test weight (TW), grain texture (\% hardness), and flour yield (FY). Test weight $\left(\mathrm{kg} \mathrm{hL}^{-1}\right)$ was determined on a sample at $500 \mathrm{ml}$ with a volumetric balance (Seedburo Equipment Co., Chicago IL.), and grain texture was determined with a near infrared spectrum reflectance analyzer (NIR) INFRATEC 1255 calibrated (method 39-70 A) [20]. Refined flour was obtained from grain samples conditioned at $14 \%$ moisture, with 24 hours rest prior to milling which was performed with a Brabender Quadrumat Senior mill (Brabender, Germany).

2.5. Chemical Analysis. Chemical analyses consisted in the determination of protein content in grain (GP) and flour (FP), sedimentation volume (SDS), and ash content of grain (ACG). Protein content in grain and flour (\%) was measured in the NIR INFRATEC 1255 (method 39-10) [20]). Sedimentation volume $(\mathrm{mL})$ was determined in a sample of $1 \mathrm{~g}$ of flour to which sodium dodecyl sulphate was added (SDS) according to the procedure written by Peña et al. [21]. Ash content (\%) was determined by calcination in a muffle furnace at $550^{\circ} \mathrm{C}$ (method 923.03) [22].

2.6. Statistical Analysis. In order to study the means effects (cycle, N, and varieties) and their interactions, a combined analysis of variance was conducted with a Minimum Honest Significant Difference (MHSD) mean test when the F test was significant (Tukey test to a significance level of 5\%) [23,24].

\section{Results}

3.1. Climatic Characterization and Statistical Analysis. During growing season of both planting dates, weather conditions were characterized by moderate precipitation 


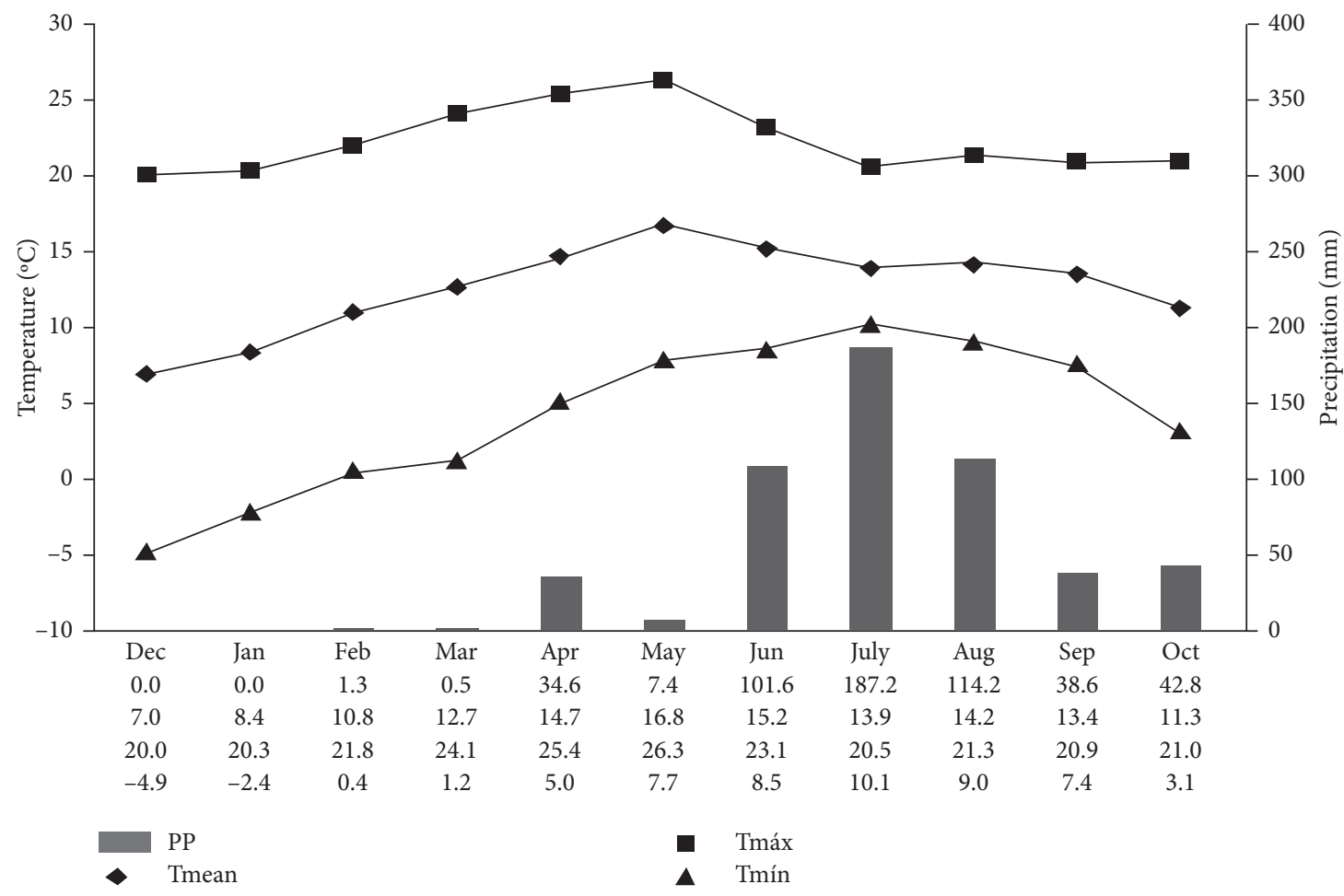

Figure 1: Monthly precipitation and temperatures in Toluca, Mexico, 2010-2011.

TABLE 1: F values for test weight (TW), hardness, flour yield (FY), ash content in grain (ACG), grain protein (GP), flour protein (FP), and sedimentation volume (SDS) determined for 9 wheat varieties under 4 nitrogen fertilization doses in Toluca, Mexico.

\begin{tabular}{|c|c|c|c|c|c|c|c|c|}
\hline \multirow{2}{*}{ F.V } & \multirow{2}{*}{$\mathrm{df}$} & \multicolumn{3}{|c|}{ Physical variables } & \multicolumn{4}{|c|}{ Chemical variables } \\
\hline & & $\mathrm{TW}\left(\mathrm{kg} \mathrm{hL}^{-1}\right)$ & Hardness (\%) & FY (\%) & ACG (\%) & GP (\%) & FP (\%) & SDS (ml) \\
\hline Cycle (C) & 1 & $1454.4^{* *}$ & $6946.7^{* *}$ & $0.9 \mathrm{~ns}$ & $100.4^{* *}$ & $62.7^{* *}$ & $10.7^{* *}$ & $518.7^{* *}$ \\
\hline Nitrogen $(\mathrm{N})$ & 3 & $0.9 \mathrm{~ns}$ & $1.3 \mathrm{~ns}$ & $0.4 \mathrm{~ns}$ & $1.2 \mathrm{~ns}$ & $8.1^{* *}$ & $8.7^{* *}$ & $3.1 \mathrm{~ns}$ \\
\hline $\mathrm{C} x \mathrm{~N}$ & 3 & $0.4 \mathrm{~ns}$ & $1.3 \mathrm{~ns}$ & $0.6 \mathrm{~ns}$ & $0.1 \mathrm{~ns}$ & $2.9 \mathrm{~ns}$ & $1.2 \mathrm{~ns}$ & $0.4 \mathrm{~ns}$ \\
\hline $\operatorname{Rep}(\mathrm{C} x \mathrm{~N})$ & 16 & $2.3^{* *}$ & $0.2 \mathrm{~ns}$ & $7.1^{* *}$ & $1.8^{*}$ & $6.2^{* *}$ & $2.4^{* *}$ & $2.4^{* *}$ \\
\hline Variety (var) & 8 & $11.1^{* *}$ & $216.4^{* *}$ & $5.2^{* *}$ & $3.8^{* *}$ & $33.8^{* *}$ & $11.1^{* *}$ & $33.8^{* *}$ \\
\hline C $x$ var & 8 & $6.5^{* *}$ & $16.44^{* *}$ & $7.3^{* *}$ & $1.5 \mathrm{~ns}$ & $12.8^{* *}$ & $5.0^{* *}$ & $13.3^{* *}$ \\
\hline $\mathrm{N} x$ var & 24 & $0.8 \mathrm{~ns}$ & $1.7^{*}$ & $1.0 \mathrm{~ns}$ & $1.3 \mathrm{~ns}$ & $3.2^{* *}$ & $1.2 \mathrm{~ns}$ & $1.0 \mathrm{~ns}$ \\
\hline $\mathrm{C} x \mathrm{~N} x$ var & 24 & $0.7 \mathrm{~ns}$ & $1.7^{*}$ & $0.7 \mathrm{~ns}$ & $0.9 \mathrm{~ns}$ & $1.6^{*}$ & $0.8 \mathrm{~ns}$ & $0.9 \mathrm{~ns}$ \\
\hline Error (CM) & 128 & 3.8 & 6.0 & 14.0 & 0.02 & 0.2 & 0.8 & 7.5 \\
\hline C.V (\%) & & 2.8 & 4.8 & 6.2 & 8.0 & 4.3 & 9.2 & 13.2 \\
\hline
\end{tabular}

${ }^{* *} P<0.001,{ }^{*} P<0.05$, and ns: not significant.

during the winter-spring (W-S) cycle which was between December and June $(145 \mathrm{~mm})$. However, for the summerautumn (S-A) cycle, high precipitation $(383 \mathrm{~mm})$, cloudy days, and low temperature during grain ripening occurred. Grain filling for the W-S cycle occurred between April and May and for S-A, between August and October (Figure 1). Possibly, environmental conditions described above affected significantly the filling and quality parameters of grain.

With the exception of flour yield (FY), all quality variables showed significant responses attributed to cycle effect. Nitrogen affected significantly GP and FP (Table 1). Nonsignificant interaction cycle $x$ nitrogen was evident. Varieties affected significantly all physical and chemical quality parameters. In the case of factor varieties, significant effects were observed for all varieties considered in this study
(Table 1 ). The interaction cycle $x$ variety was present significantly in all variables with the exception of ash percentage, while nitrogen $x$ variety interaction affected only hardness. GP variables were significant as well as cycle $x$ nitrogen $x$ variety interaction. Coefficients of variation ranged between 2.8 and $13.2 \%$ for TW and SDS, respectively (Table 1).

3.2. Mean Values for the Studied Factors. Growing season was the most important factor because weather conditions that occurred during each cycle affected the physical and chemical properties of wheat, with a strong influence of the environment being observed on the variables that determined grain quality. With the exception of flour yield, all 
TABLE 2: Mean values for test weight (TW), hardness, flour yield (FY), ash content in grain (ACG), grain protein (GP), flour protein (FP), and sedimentation volume (SDS) for nine wheat cultivars under 4 nitrogen fertilization rates in Toluca, Mexico.

\begin{tabular}{|c|c|c|c|c|c|c|c|}
\hline & \multicolumn{3}{|c|}{ Physical variables } & \multicolumn{4}{|c|}{ Chemical variables } \\
\hline & $\mathrm{TW}\left(\mathrm{kg} \mathrm{hL}^{-1}\right)$ & Hardness (\%) & FY (\%) & ACG (\%) & GP (\%) & FP (\%) & $\mathrm{SDS}(\mathrm{mL})$ \\
\hline \multicolumn{8}{|l|}{ Cycle } \\
\hline W-S & $76.6 \mathrm{a}$ & $58.5 \mathrm{a}$ & $60.2 \mathrm{a}$ & $2.1 \mathrm{a}$ & $11.0 \mathrm{~b}$ & $9.5 b$ & $14.1 \mathrm{~b}$ \\
\hline S-A & $61.3 \mathrm{~b}$ & $43.9 \mathrm{~b}$ & $58.8 \mathrm{a}$ & $1.8 \mathrm{~b}$ & $12.3 \mathrm{a}$ & $10.1 \mathrm{a}$ & $27.4 \mathrm{a}$ \\
\hline \multicolumn{8}{|l|}{ Nitrogen } \\
\hline 0 & $69.2 \mathrm{a}$ & $51.3 \mathrm{a}$ & $59.8 \mathrm{a}$ & $1.9 \mathrm{a}$ & $11.0 \mathrm{~b}$ & $9.0 \mathrm{~b}$ & $19.5 b$ \\
\hline 100 & $69.4 \mathrm{a}$ & $51.4 \mathrm{a}$ & $59.8 \mathrm{a}$ & $1.9 \mathrm{a}$ & $11.7 \mathrm{a}$ & $9.9 \mathrm{a}$ & $20.4 \mathrm{ab}$ \\
\hline 200 & $68.9 a$ & $51.1 \mathrm{a}$ & $60.3 a$ & $1.9 \mathrm{a}$ & $11.8 \mathrm{a}$ & $10.0 \mathrm{a}$ & $21.3 \mathrm{ab}$ \\
\hline 300 & $68.5 \mathrm{a}$ & $50.9 \mathrm{a}$ & $58.1 \mathrm{a}$ & $1.9 \mathrm{a}$ & $12.1 \mathrm{a}$ & $10.3 \mathrm{a}$ & $21.9 \mathrm{a}$ \\
\hline \multicolumn{8}{|l|}{ Variety } \\
\hline Salamanca S75 & $61.9 \mathrm{cb}$ & $54.0 \mathrm{c}$ & $59.2 \mathrm{cde}$ & $1.9 \mathrm{bc}$ & $11.2 \mathrm{e}$ & $9.4 \mathrm{~b}$ & $19.9 \mathrm{~cd}$ \\
\hline Saturno S86 & $69.2 \mathrm{bc}$ & $55.2 \mathrm{bc}$ & $59.3 \mathrm{cde}$ & $1.9 \mathrm{bc}$ & $11.3 \mathrm{de}$ & $9.4 \mathrm{~b}$ & $19.7 \mathrm{dc}$ \\
\hline Eneida F94 & $69.6 \mathrm{~b}$ & $41.2 \mathrm{e}$ & $61.4 \mathrm{ab}$ & $1.9 b c$ & $12.0 \mathrm{c}$ & $10.7 \mathrm{a}$ & $27.9 \mathrm{a}$ \\
\hline Cortazar S94 & $66.8 \mathrm{e}$ & $56.1 \mathrm{~b}$ & $59.4 \mathrm{bcd}$ & $2.0 \mathrm{a}$ & $11.5 \mathrm{~d}$ & $9.5 b$ & $18.7 d$ \\
\hline Rebeca F00 & $71.3 \mathrm{a}$ & $40.2 \mathrm{e}$ & $57.4 \mathrm{de}$ & $1.8 \mathrm{c}$ & $10.8 \mathrm{f}$ & $9.1 \mathrm{~b}$ & $20.6 c$ \\
\hline Barcenas S02 & $67.7 \mathrm{de}$ & $60.0 \mathrm{a}$ & $59.6 \mathrm{bc}$ & $1.9 \mathrm{ab}$ & $11.5 \mathrm{~d}$ & $9.6 \mathrm{~b}$ & $20.5 c$ \\
\hline Tollocan F05 & $70.0 \mathrm{~b}$ & $43.6 \mathrm{~d}$ & $62.8 \mathrm{a}$ & $1.9 \mathrm{bc}$ & $12.4 \mathrm{~b}$ & $10.4 \mathrm{a}$ & $23.9 b$ \\
\hline Maya S07 & $69.0 \mathrm{bc}$ & $54.8 \mathrm{bc}$ & $57.2 \mathrm{e}$ & $1.9 \mathrm{bc}$ & $11.4 \mathrm{de}$ & $9.5 b$ & $18.7 \mathrm{de}$ \\
\hline Urbina S07 & $68.1 \mathrm{~cd}$ & $55.8 \mathrm{~b}$ & $59.4 \mathrm{bcd}$ & $2.0 \mathrm{a}$ & $12.8 \mathrm{a}$ & $10.7 \mathrm{a}$ & $17.1 \mathrm{e}$ \\
\hline
\end{tabular}

Means with the same letter do not differ with the Tukey test $(P<0.05)$.

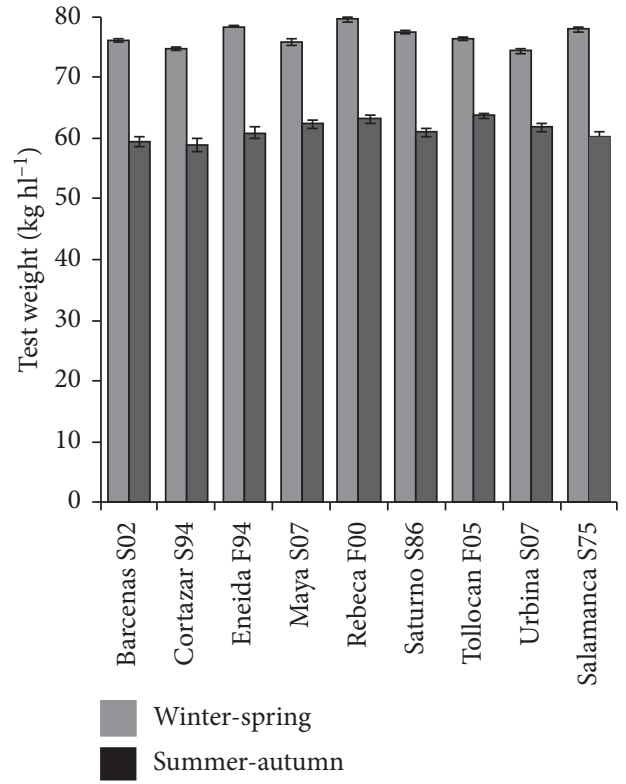

(a)

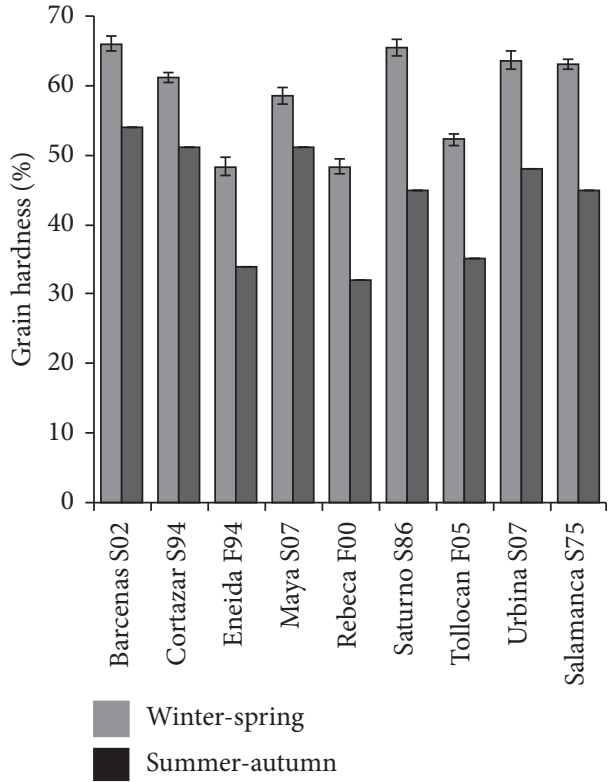

(b)

Figure 2: Continued. 


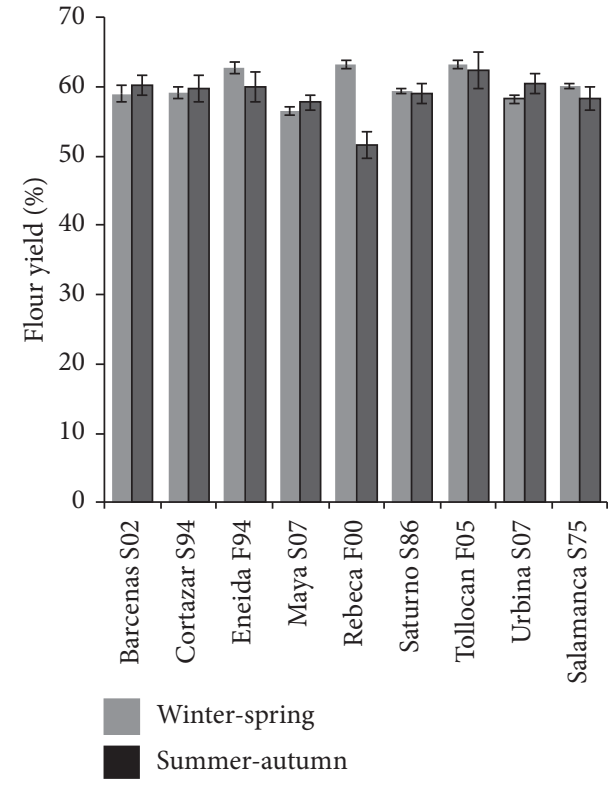

(c)

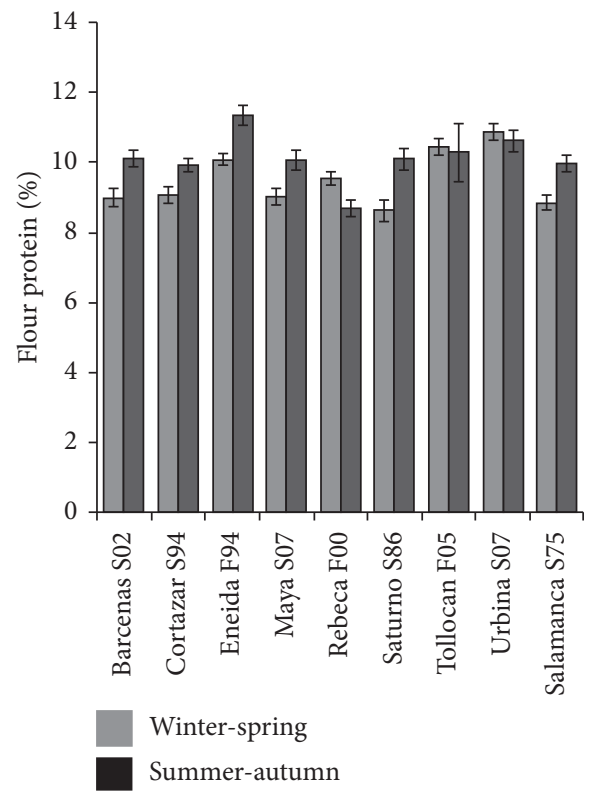

(e)

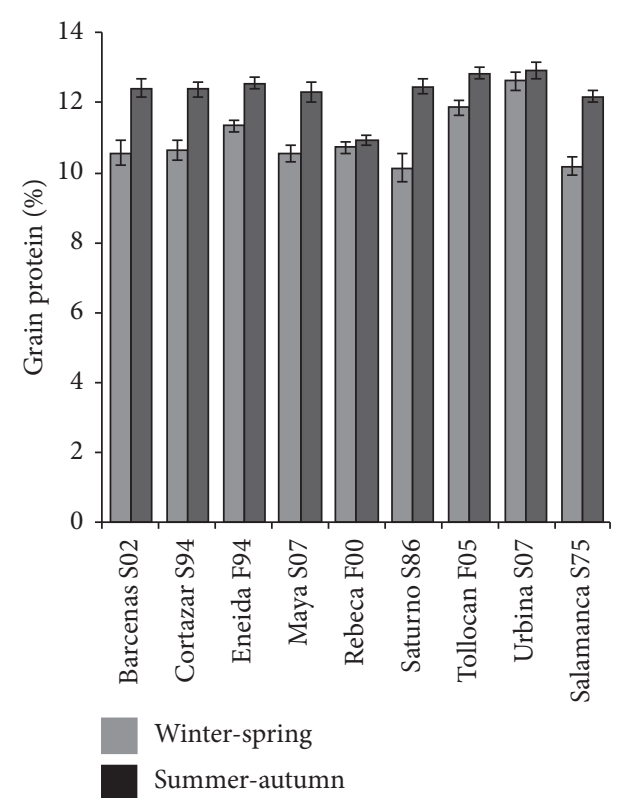

(d)

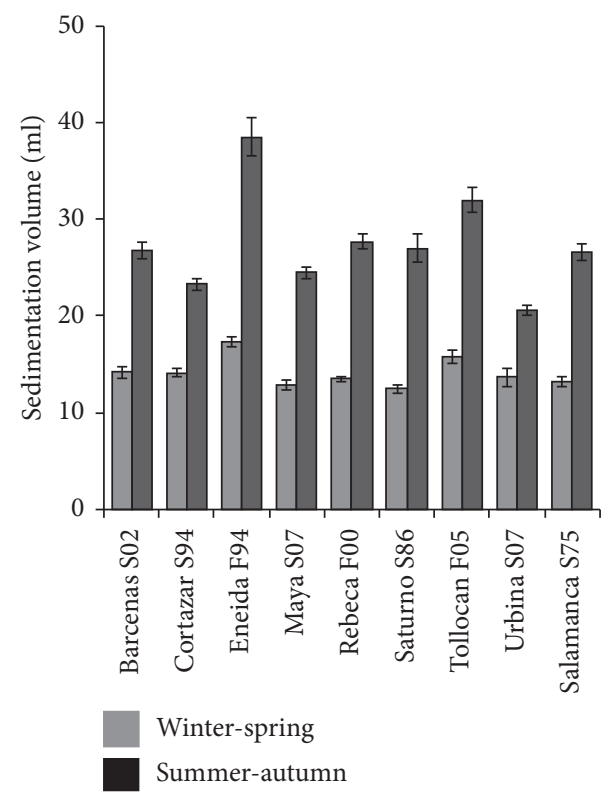

(f)

Figure 2: Mean values for variables test weight $\left(\mathrm{k} \mathrm{hL}^{-1}\right)$. (a) Hardness, (b) flour yield, (c) grain protein, (d) flour protein, and (e) sedimentation volume, (f) for 9 wheat varieties grown in 2 cycles. Bars on the top of the columns indicate standard error.

quality variables were affected by growing season, where under rainfed conditions test weight, grain hardness, and ash content $(20,25$ and $14 \%)$ decreased significantly $(P<0.05)$ compared to irrigation cycle. However, grain protein content, flour protein, and sedimentation increased significantly by 12,6 , and $94 \%$, respectively (Table 2 ). On the other hand, it was observed that nitrogen treatments $\left(\mathrm{N}_{00}, \mathrm{~N}_{100}, \mathrm{~N}_{200}\right.$ and $\mathrm{N}_{300}$ ) did not affect test weight, hardness, flour yield, and ash content (Table 2). Grain protein increased significantly (6, $7 y 10 \%$ ) with $\mathrm{N}$ rates of $\mathrm{N}_{100}, \mathrm{~N}_{200}$, and $\mathrm{N}_{300}$, respectively, compared to the unfertilized control. Protein flour increased
$14 \%$ with $\mathrm{N}_{300}$, while sedimentation volume increased in 5, 9 y $12 \%$ with $\mathrm{N}_{100}, \mathrm{~N}_{200}$, and $\mathrm{N}_{300}$, when compared to the control (Table 2). Cultivars Rebeca F00, Tollocan F05, and Eneida F94 showed the highest test weight; however, only Eneida F94 sticks out for its high flour yield. Cultivars Cortazar S94 and Barcenas S02 exceeded the average grain hardness by $16 \%$. This parameter is important in determining the potential use of wheat in the bakery industry. Cultivars Urbina S07 and Tollocan F05 outperformed the rest of the cultivars in grain protein (12.8 and 12.4\%), while Eneida F94 and Urbina S07 outperformed flour content 


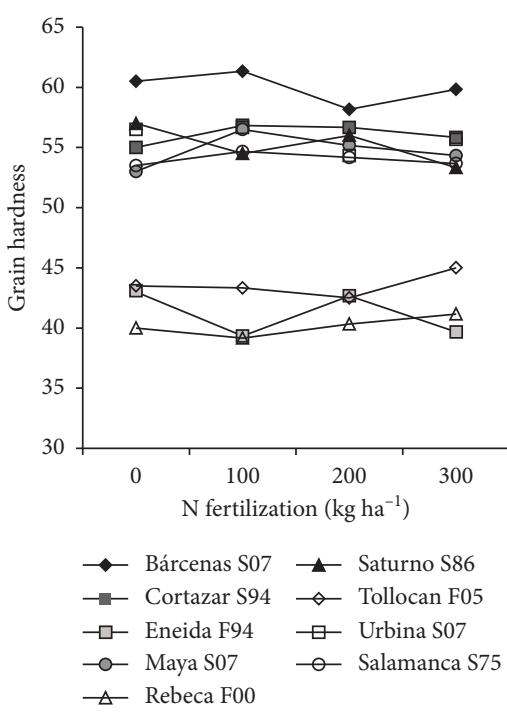

(a)

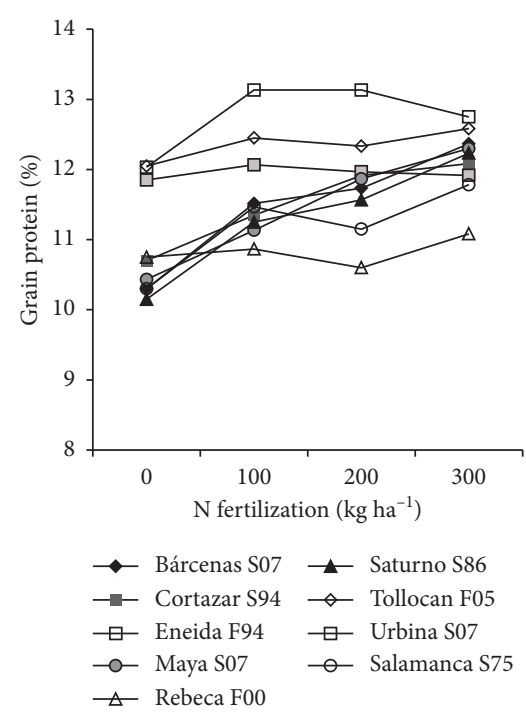

(b)

Figure 3: Relationship between grain hardness (a), grain protein (b), and nitrogen (N) fertilization rate in nine varieties of wheat.

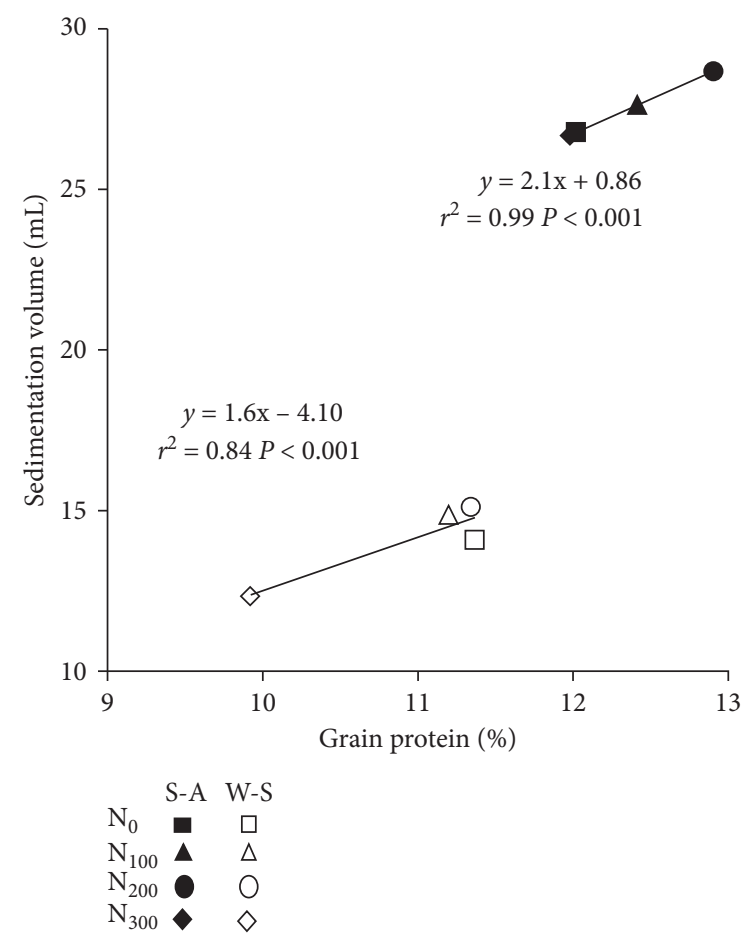

FIGURE 4: Relationship between sedimentation volume and grain protein for nine wheat cultivars grown under four nitrogen rate and two growing seasons, summer-autumn (S-A) and winter-spring (W-S). Data correspond to average of cultivars.

protein with $10.7 \%$ to the rest. Cortazar S94 and Urbina S07 varieties showed values of $2 \%$ differing significantly from other varieties (Table 2). Regarding sedimentation volume, the varieties Eneida F94 and Tollocan F05 excelled with values of 28 and $24 \mathrm{~mL}$, indicating that proteins of these varieties may be more related to the strength of the dough (gluten strength) during bread-making.
For the W-S cycle, all varieties showed the highest values of TW and hardness; Eneida F94, Rebeca F00, and Tollocan F05 showed the highest FY in both cycles from the remaining 6 varieties. The highest percentages of GP were achieved in S-A, standing out again the varieties Eneida F94, Rebeca F00, and Tollocan F05. Higher percentages of FP were observed in S-A in 6 of the 9 varieties; likewise, highest values of SDS were obtained for all varieties evaluated (Figure 2).

Grain hardness was significantly larger in five out of nine cultivars (Barcenas S02, Cortazar S94, Maya S07, Saturno S86, and Urbina S07) without significant changes between N doses. Tollocan F05 and F94 Eneida cultivars showed less grain hardness but higher protein content than the other cultivars. It is important to point out that the response saturation grain protein appears to have been set at $100 \mathrm{~kg} \mathrm{~N} \cdot \mathrm{ha}^{-1}$. Interestingly, for the same dose of N, grain protein was different in each cultivar (Figure 3). The relationship between sedimentation volume and grain protein was positive and statistically significant with an increase due to $\mathrm{N}$ fertilization rate (Figure 4).

\section{Discussion}

Environmental conditions, primarily those prevailing during the grain filling (rainfall and low temperatures in the S-A cycle), in both crop cycles affected some quality parameters (test weight) and composition of grain protein which could cause problems in the marketing of grain to the milling industry $[16,25]$. Growing season caused changes in the physical quality attributes of the grain (TW, hardness, FY, and ACG) being higher in the WS cycle compared to the SA cycle. The difference could be attributed to drier conditions in the WS cycle, such as a higher average temperature, lower cloud cover, and good radiation incidence during grain filling $[26,27]$. Conversely, GP, FP, and SDS were negatively affected under conditions of the W-S cycle, possibly 
attributed to cooler temperatures during grain filling, thus enabling a higher accumulation of protein.

In terms of bread quality, accumulation of protein occurs during grain filling, with gliadins being the first to be deposited at about 5-10 days and glutenins which are detectable around 20 days. If any alteration process takes place during grain development in this stage, grain will exhibit a different composition (gliadins:glutenins) [28]. Our results showed that the commercial quality of wheat was affected by growing season (cycle) indicating that physical properties of wheat grain are characteristics highly influenced by the environment, irrigation or rainfed [29], growing season, and cultivar [30], while others found that year effect was the principal environment factor in defining wheat quality $[16,29]$.

Grain's protein content is related to the amount of nutrients ( $\mathrm{N}$ mainly) in the soil; lower amount of protein means lower $\mathrm{N}$ content in the plant at the stage of appearance of the first node and next stages [31]. In rainfed conditions, the strategy of application of $\mathrm{N}$ fertilizer depends basically on edaphic $\mathrm{N}$ interactions with rainfall and potential crops requirements [32]. The interaction of nitrogen $x$ variety showed that Barcenas S2002, Cortazar S94, Maya S2007, Saturno S86, and Urbina S2007 varieties increased significantly grain hardness when $\mathrm{N}$ rate was increased, while Urbina S2007, Tollocan F2005, and Eneida F94 cultivars obtained higher values of GP with a dose of 100 and $200 \mathrm{~kg} \mathrm{~N} \cdot \mathrm{ha}^{-1}$. This is consistent with the work of Lerner et al. [33], who mentions that percentages of protein were significantly higher in treatments with $\mathrm{N}$, finding a considerable difference between varieties and years. On the other hand, Souza et al. [34] showed that values of grain hardness were influenced by the variety, season, and $\mathrm{N}$ rate.

Wheat sowing in rainfall conditions showed lower values of TW, hardness, and ACG when compared to wheat under irrigation conditions; conversely, values of protein and sedimentation had a significant increase. Lowest values of TW could be due to the shortest period available for grain filling, so it is important to identify varieties to achieve short cycle crops with good grain quality, since a sucked grain is not acceptable for milling due to its low yield flour [12]. On the other hand, the high values of protein can be attributed to the low test weight, which is defined mainly by genotype; which could be affected positively or negatively by late showing dates, deficiency of $\mathrm{N}$, availability of water, and high humidity in the stage of filling [12].

Grain ash content is very important because high ash values are related to grains of low-test weight promoting contamination of flour and semolina; therefore, the desirable levels must be less than 2\% [35]. According to the results of the present study, all the varieties showed an acceptable ash content (1.8-1.9\%) which is an acceptable value for baking [36]. The highest values of SDS obtained were shown in rainfall conditions compared with irrigation, indicating irrigation during grain filling reduces sedimentation volume [36].

All varieties showed significant effects when evaluating quality variables, and the highest values of TW and FY were obtained in the varieties Eneida F94 and Tollocan F2005 which make them suitable for baking [35]. The hardness of the grain showed variability between varieties, prevailing more varieties of grain of semihard texture $(<56 \%)$ as Salamanca S75, Eneida F94, Saturno S86, Rebeca F2000, Urbina S2007, Maya S2007, and Tollocan F2005. Meanwhile, Cortazar S94 and Barcenas S2002 are texture catalogued as varieties of semisoft grain (56-62\%); this parameter is important since it determines the potential use of wheat for the cookies production (soft to semisoft), bread (from semisoft until hard), or mixtures of flour for bread making (soft wheat to semisoft with semihard wheat to durum) [12]. In general, all varieties showed an acceptable protein content similar to that reported by Peña et al. [35] who evaluated the quality of wheat, finding that some wheat varieties showed low ash content in spite of their low test weight $\left(71.1 \mathrm{~kg} \cdot \mathrm{hL}^{-1}\right)$ but excellent protein content.

The quality of the wheat grain depends on their genetic composition, agronomic management, and on the environment $[4,12]$. Thus, results of the present study indicated that the effect of the availability of the $\mathrm{N}$ increases the quantity of the wheat protein, obtaining good quality standards mainly under irrigation conditions, which suggests that sowing in winter-spring would allow obtaining good baking quality wheat. Given the acceptable values of protein, test weight, hardness, and SDS observed in this study, it would be interesting to analyze the rheological characteristics and baker's quality of the flour.

\section{Conclusions}

Genetic and environmental variability were observed to be determinant in assessing the quality attributes during the winter-spring cycle. $\mathrm{N}$ availability modified significantly the grain and flour protein. Winter-spring cycle with a rate of $100 \mathrm{~kg} \mathrm{~N} \cdot \mathrm{ha}^{-1}$ obtained the highest values of grain and flour protein, test weight, and grain hardness, whereas with a 300 $\mathrm{kg} \mathrm{N} \cdot \mathrm{ha}^{-1}$ dose only sedimentation volume showed positive effects. The summer-autumn cycle was favorable in grain and flour protein, sedimentation volume, and hardness when using a $300 \mathrm{~kg} \mathrm{~N} \cdot \mathrm{ha}^{-1}$ dose. Eneida F94, Tollocan F2005, and Urbina S2007 varieties showed the highest grain and flour protein content. Likewise, Eneida F94 and Tollocan F2005 varieties showed high test weight and flour yield values suggesting its use for baking, while the rest of the varieties can be used for the biscuit industry.

\section{Data Availability}

The data used to support the findings of this study are included within the article.

\section{Conflicts of Interest}

The authors declare that there are no conflicts of interest regarding the publication of this article.

\section{Acknowledgments}

The authors thank the Autonomous Universidad Autonoma del Estado de México (UAEM) for their support for this 
study, which is part of the research project "Determinants ecophysiological performance attributes in wheat and barley in response to nitrogen fertilization "key"2860/2010U". CVV held a postgraduate scholarship from CONACYT (Consejo Nacional de Ciencia y Tecnología).

\section{References}

[1] C. Valdes-Valdes, "Cambios en la calidad harinera y panadera de trigo en respuesta a la fertilización nitrogenada," Tesis de Maestría, p. 106, Universidad Autónoma del Estado de México, Toluca, Mexico, 2013.

[2] B. J. Peterson, T. Corliss, K. Kriet, and J. E. Hobbie, "Nitrogen and phosphorus concentrations and export for the upper kuparuk river on the north slope of Alaska in 1980," Hydrobiologia, vol. 240, pp. 61-69, 1992.

[3] Y. Rharrabti, D. Villegas, L. F. G. Del Moral, N. Aparicio, S. Elhani, and C. Royo, "Environmental and genetic determination of protein content and grain yield in durum wheat under Mediterranean conditions," Plant Breeding, vol. 120, no. 5, pp. 381-388, 2001.

[4] R. E. Espitia, B. R. J. Peña, M. H. E. Villaseñor, E. J. Huerta, and O. A. Limón, "Calidad industrial de trigos harineros mexicanos para temporal. I. Comparación de variedades y causas de la variación," Revista Fitotecnia Mexicana, vol. 26, pp. 249-256, 2003.

[5] G. Branlard, M. Dardevet, R. Saccomano, F. Lagoutte, and J. Gourdon, "Genetic diversity of wheat storage proteins and bread wheat quality," Euphytica, vol. 119, no. 1-2, pp. 59-67, 2001.

[6] I. Pasha, F. M. Anjum, and C. F. Morris, "Grain hardness: a major determinant of wheat quality," Food Science and Technology International, vol. 16, no. 6, pp. 511-522, 2010.

[7] M. Hrušková and I. Švec, "Wheat hardness in relation to other quality factors," Czech Journal of Food Sciences, vol. 27, pp. 240-248, 2009.

[8] Y. Pomeranz and P. C. Williams, "Wheat hardness: it's genetic, structural and background, measurement and significance," in Advance in Cereal Science and Technology, Y. Pomeranz, Ed., AACC Inc., St. Paul, MN, USA, 1990.

[9] C. S. Gaines, P. L. Finney, and L. C. Andrews, "Influence of kernel size and shriveling on soft wheat milling and baking quality," Cereal Chemistry Journal, vol. 74, no. 6, pp. 700-704, 1997.

[10] C. Saint Pierre, C. J. Peterson, A. S. Ross et al., "White wheat grain quality changes with genotype, nitrogen fertilization, and water stress," Agronomy Journal, vol. 100, no. 2, pp. 414-420, 2008.

[11] R. A. Graybosch, C. J. Peterson, P. S. Baenziger, and D. R. Shelton, "Environmental modification of hard red winter wheat flour protein composition," Journal of Cereal Science, vol. 22, no. 1, pp. 45-51, 1995.

[12] B. R. J. Peña, Influencia de la textura del endospermo y la composición de las proteínas del gluten en la calidad panadera del trigo. C. Jobet (ed), Avances y Perspectivas en la Calidad Industrial del Trigo. Serie Acta No. 21. INIA. Chile, pp. 23-40, 2003.

[13] C. Luo, G. Branlard, W. Griffin, and D. McNeil, "The effect of nitrogen and sulphur fertilisation and their interaction with genotype on wheat glutenins and quality parameters," Journal of Cereal Science, vol. 31, no. 2, pp. 185-194, 2000.

[14] P. R. Shewry, N. G. Halford, A. S. Tatham, Y. Popineau, D. Lafiandra, and P. S. Belton, "The high molecular weight subunits of wheat glutenin and their role in determining wheat processing properties," Advances in Food and Nutrition Research, vol. 45, pp. 219-302, 2003.

[15] S. B. Altenbach, F. M. DuPont, K. M. Kothari, R. Chan, E. L. Johnson, and D. Lieu, "Temperature, water and fertilizer influence the timing of key events during grain development in a US spring wheat," Journal of Cereal Science, vol. 37, no. 1, pp. 9-20, 2003.

[16] Y. Rharrabti, C. Royo, D. Villegas, N. Aparicio, and L. F. García del Moral, "Durum wheat quality in Mediterranean environments," Field Crops Research, vol. 80, no. 2, pp. 123-131, 2003.

[17] M. Ayoub, D. L. Smith, and J. Fregeau-Reid, "Evaluation of the SDS-sedimentation test for the assessment of eastern Canadian bread wheat quality," Canadian Journal of Plant Science, vol. 73, no. 4, pp. 995-999, 1993.

[18] C. Saint Pierre, C. J. Peterson, A. S. Ross et al., "Winter wheat genotypes under different levels of nitrogen and water stress: changes in grain protein composition," Journal of Cereal Science, vol. 47, no. 3, pp. 407-416, 2008.

[19] E. García, Modificaciones al Sistema de Clasificación Climática de Köppen, p. 246, Instituto Nacional de Geografía. Universidad Nacional Autónoma de México, Mexico City, Mexico, 1988.

[20] American Association of Cereal Chemists (AACC), Approved Methods of the American Association of Cereal Chemists, p. 1268, American Association of Cereal Chemists (AACC), St. Paul, MN, USA, 9th edition, 1995.

[21] R. J. Pena, A. Amaya, S. Rajaram, and A. Mujeeb-Kazi, "Variation in quality characteristics associated with some spring 1B/1R translocation wheats," Journal of Cereal Science, vol. 12, no. 2, pp. 105-112, 1990.

[22] Association of Official Analytical Chemists (AOAC), Official Methods of Analysis of the AOAC, Association of Official Analytical Chemists (AOAC), Washington, DC., USA, 16th edition, 1999.

[23] R. C. Littell, G. A. Milliken, W. W. Stroup, and R. D. Wolfinger, $S A S^{\circledR}$ System for mixed models, p. 633, SAS Institute Inc., Cary, CA, USA, 1996.

[24] U. R. Palaniswamy and K. M. Palaniswamy, Handbook of Statistics for Teaching and Research in Plant and Crop Science, p. 624, The Harworth Press, Inc., New York, NY, USA, 2006.

[25] Z. A. Salazar, "Calidad industrial del trigo para su comercialización," in En: El Trigo de Temporal en México, M. H. E. Villaseñor and R. E. Espitia, Eds., Campo Experimental Valle de México, p. 313, INIFAP, Chapingo, Estado de México, MexicoINIFAP, 2000.

[26] A. Abad, J. Lloveras, and A. Michelena, "Nitrogen fertilization and foliar urea effects on durum wheat yield and quality and on residual soil nitrate in irrigated Mediterranean conditions," Field Crops Research, vol. 87, no. 2-3, pp. 257-269, 2004.

[27] Z. Yong, H. Zhonghu, G. Ye, Z. Aimin, and M. Van Ginkel, "Effect of environment and genotype on bread-making quality of spring-sown spring wheat cultivars in China," Euphytica, vol. 139, no. 1, pp. 75-83, 2004.

[28] P. Stone and M. Nicolas, "Wheat cultivars vary widely in their responses of grain yield and quality to short periods of postanthesis heat stress," Functional Plant Biology, vol. 21, no. 6, pp. 887-900, 1994.

[29] O. M. Olán, R. E. Espitia, S. H. López, M. H. E. Villaseñor, B. R. J. Peña, and H. J. Herrera, "Calidad física de grano de trigos harineros (Triticum aestivum L.) mexicanos de temporal," Revista Mexicana de Ciencias Agrícolas, vol. 3, no. 2, pp. 271-283, 2012. 
[30] J. S. Swanston, P. L. Smith, R. C. Agu, J. M. Brosnan, T. A. Bringhurst, and F. R. Jack, "Variation, across environments within the UK, in grain protein and grain hardness, in wheat varieties of differing distilling quality," Field Crops Research, vol. 127, pp. 146-152, 2012.

[31] D. B. Fowler, "The importance of crop management and cultivar genetic potencial in the production of wheat with hight protein concentration," in Wheat Protein Production and Marketing, pp. 285-290, University Extension Press, University of Saskatchewan, Saskatoon, Canada, 1998.

[32] A. Bauer, A. L. Black, and A. B. Frank, "Nitrogen fertilization in relation to spring wheat development stage," in Kansas State University Proceedings of the Great Plains Soil Fertility Conference, pp. 129-136, Kansas State University, Manhattan, KS (USA), 1992.

[33] S. E. Lerner, A. C. Arrigoni, and A. F. Arata, "Uso del nitrógeno y calidad industrial en cultivares argentinos de trigo pan (Triticum aestivum L.)," Revista de Investigación Agropecuaria, vol. 39, pp. 77-87, 2013.

[34] E. J. Souza, J. M. Martin, M. J. Guttieri et al., "Influence of genotype, environment, and nitrogen management on spring wheat quality," Crop Science, vol. 44, pp. 425-432, 2004.

[35] B. R. J. Peña, H. P. Pérez, M. H. E. Villaseñor, V. M. M. Gómez, L. M. A. Mendoza, and G. R. Monterde, Calidad de la cosecha del trigo en México. Ciclo otoño-invierno 2005-2006, p. 24, Publicación Especial del CONASIST, México, D. F., mexico, 2007.

[36] Y. Rharrabti, D. Villegas, C. Royo, V. Martos-Núñez, and L. F. García del Moral, "Durum wheat quality in Mediterranean environments," Field Crops Research, vol. 80, no. 2, pp. 133-140, 2003. 